\title{
ПЕРСПЕКТИВА ЗАСТОСУВАННЯ У ЗАКЛАДАХ ВИЩОЇ МЕДИЧНОЇ ОСВІТИ МЕТОДІВ ВИПЕРЕДЖУЮЧОГО НАВЧАННЯ
}

К. В. Аймедов

\author{
Одеський національний медичний університет
}

\section{THE PROSPECT OF APPLICATION IN EDUCATIONAL INSTITUTIONS OF THE METHODS OF FORESTALLING LEARNING}

K. V.Aymedov

\author{
Odesa National Medical University
}

\begin{abstract}
Стрімке зростання кількості та ваги інформації, що використовує сучасна людина, веде до практичної неефективності багатьох традиційних методів навчання в існуючій системі освіти, тому необхідно відзначити, що перехід до інформаційного суспільства - це сдиний процес руху цивілізації по шляху розвитку. Автором наведено можливі реалізації цієї концепції на прикладі надання вищої медичної освіти, за допомогою застосування випереджуючих методів навчання.
\end{abstract}

Swift growth of amount and weight of information, that a modern man used leads to practical inefficiency of many traditional methods of learning. So, necessary to mark that a transition to informative society is the unique process of motion of civilization on the way of development. The author presents the possible realization of this conception on the example of providing the higher medical education, with the help of application of forestalling methods of education.

Вступ. Удосконалення технологій освіти серед іншого має на увазі впровадження нових освітніх технологій іпринципів організації процесу навчання у закладах вищої освіти, що забезпечують ефективну реалізацію нових моделей безперервної освіти, у тому числі з використанням сучасних інформаційних й комунікаційних технологій. Важливим є ще один істотний елемент сучасних змін -це перехід від друкарських форм зберігання та передачі інформації до електронної або цифрової.

Основна частина. Процеси реформування освіти зумовлені процесами розвитку сучасного інформаційного суспільства, концепція якого $є$ різновидом теорії постіндустріального суспільства, що була описана у роботах Т. Стоуньера та Д. Белла, де стверджується, що капітал та праця як основа індустріального суспільства поступаються місцем інформації й знанням в інформаційному суспільстві [1]. Постійне зростання кількості та ролі інформації, що використовується сучасною людиною, веде до неефективності багатьох традиційних методів навчання в існуючій системі освіти. Необхідно відзначити, що перехід до інформаційного суспільства-цеєдиний процес руху цивілізації по шляху “стійкого розвитку” [2].

Модель “стійкого розвитку” має на увазі таке перетворення механізмів відтворення, при якому головним носієм стійкого розвитку стає суспільний інтелект. При цьому суспільний інтелект визначається як сукупний інтелект суспільства, в якому виражається єдність суспільної свідомості та суспільного знання, єдність соціальних інститутів науки, культури і освіти. У свою чергу, освіта - це провідний механізм розвитку суспільного інтелекту [3]. “Стійкий розвиток” має на увазі випереджаючий розвиток якості суспільного інтелекту по відношенню до зростання складності та динаміки соціально-економічних змін, що має на увазі випереджаючий розвиток якості освіти, починаючи від початкового, середнього та закінчуючи вищим.

Сенс закону випереджаючого розвитку якості людини полягає в якості освітніх систем у суспільстві та якості суспільного інтелекту, як здатність людства виживати у світовій цивілізації. Вважається, що ідея випереджаючої освіти належить професору А. Д. Урсулу [4]. Вона є логічним наслідком його філософського висновку про необхідність випередження буття свідомістю у період переходу суспільства на модель стійкого розвитку та формування цивілізації, заснованої на знаннях.

Головний зміст цієї ідеї полягає у тому, що перспективна система освіти як одну із своїх пріоритетних цілей повинна мати завдання формувати у людини такі якості, які дозволять їй успішно адаптуватися, жити та працювати в сучасних умовах. Орієнтація на майбутнє $є$ ключовою ідеєю випереджаючої осві- 
ти. У цих обставинах інформатизація освіти є однією 3 найважливіших умов успішного розвитку процесів інформатизації суспільства, оскільки саме у сфері освіти готуються та виховуються ті люди, які не лише формують нове інформаційне середовище суспільства, але які також живуть та працюють у цьому новому середовищі.

Виходячи з вищенаданої теорії, нами, з урахуванням особливостей навчання у системі вищої медичної освіти, запропоновано шлях із реалізації концепції випереджуючого навчання, що передбачає знайомство 3 клінікою та аспектами співпраці лікаря з пацієнтом вже 3 перших кроків спеціалізованої освіти. Впроваджувати у практику це можливо за допомогою спеціалізованих практичних занять у лікарнях різного профілю та введення у навчальну програму ознайомчих дисциплін якомога раніше. Наприклад, за допомогою таких предметів, як вступ до спеціальності лікаря, особливостей догляду за хворим, деонтології, біоетики та нооетики у сучасній медицині тощо. Головна мета такого підходу до виховання майбутнього спеціаліста - надати йому можливість 3 перших кроків професійного навчання побачити практично весь шлях, який він повинен пройти у власному майбутньому. Таким чином, ми зменшуємо стресове навантаження від невідомого, що з'являється перед студентом на кожному наступному курсі навчання, адаптуємо його до тривалого інформаційного навантаження, формуючи так звану психологічну готовність. I, взагалі, це - можливість ще раз визначитися, чи ту спеціальність він обрав.

Для досягнення цієї мети необхідно впроваджува-

\section{Література}

1. Лысенкова С. Н. Жизнь моя — школа, или Право на творчество / С. Н. Лысенкова. - М. : Изд-во “Новая школа”, 1995. -№ 3.-C. 34-37.

2. Аржанцева Т. В. Методика опережающего обучения синтаксису русского языка учащихся 5-х классов общеобразовательных школ с русским языком обучения : дис... канд. пед. наук: 13.00.02 / Т. В. Аржанцева. -Симф., 2006. $277 \mathrm{c}$.

3. Белл Д. Грядущее постиндустриальное общество : Опыт ти такі засоби випереджаючої освіти, як забезпечення системного етичного, естетичного й наукового світосприйняття та світогляду, впровадження навчання. Необхідно звернути увагу на рефлексію, самопізнання та саморозвиток, організацію практичної діяльності, спілкування, взаємодопомогу і співпрацю, розвиток й компенсацію здібностей, застосування в навчально-виховному процесі нових інформаційних технологій та засобів комп'ютерної комунікації [5].

Висновок. В цілому, інформаційна культура $є$ властивістю особи, формування якої залежить від міри інформатизації суспільства, причому розвиток цієї властивості сприяє гуманістичній спрямованості процесу інформатизації.

Формування і розвиток інформаційної культури особи буде найбільш ефективним, якщо воно здійснюється в системі освіти на всіх іiі етапах через безперервне впровадження засобів інформаційно-комунікативних технологій у вміст та форму всього навчально-виховного процесу ВНЗ.

Сучасні інформаційні технології-це комплекс засобів обробки інформації за допомогою комп'ютерів і всілякого програмного забезпечення. Інформаційні технології, на наш погляд, найефективніше взаємодіють 3 такими педагогічними технологіями, як “вчення в співпраці", метод проектів, проблемне та різнорівневе вчення, особово-орієнтоване та дистанційне навчання й відкрита освіта.

Виходячи з точки зору педагогічної практики, саме інформаційні технології дозволяють повною мірою розкрити педагогічні, дидактичні функції цих методів, реалізувати закладені в них потенційні можливості.

социального прогнозирования / Д. Белл. - М. : Academia, 1999. $-256 \mathrm{c}$.

4. Ушинский К. Д. Человек как предмет воспитания. Опыт педагогической антропологии / К. Д. Ушинский // Избр. пед. соч. : в 2 т. - М., 1974. - Т. 1.-С. 274.

5. Гузеев В. В. Современные образовательные технологии / В. В. Гузеев // Советская педагогика. - 1989. - № 2.C. 51-55. 